\title{
EVALUATION OF INDOOR COMFORT AND BUILDING ENERGY PERFORMANCE OF STUDENTS RESIDENCE AT SAM RATULANGI UNIVERSITY IN MANADO, INDONESIA
}

\author{
Sangkertadi \\ Department of Architecture, Faculty of Engineering, Sam Ratulangi University \\ e-mail: t_sangkertadi@yahoo.com
}

\begin{abstract}
There is no information that the student residence of Sam Ratulangi University is especially designed energy-efficient. It is necessary to evaluate the design from the view point of energy conservation associated with the fulfillment of indoor comfort. Through this study, observation, measurements and calculations of comfort, ventilation, heat and lighting were performed to get information if the design follows the Indonesia standards on comfort and energy conservation. Questionnaires to residents were also conducted to obtain compliance response to the comfort standard. Air temperature, wind speed, humidity and lighting were measured, simultaneously with a questionnaire regarding the level of comfort to occupants. Scale of the thermal comfort in the room refers to the ISO-7748. The use of electronic devices such as computers, fan, $T V$, etc. are also recorded to determine the level of electrical energy consumption. The results generally indicate that there are differences in comfort perception between the level based on references and by the respondents. Overall, the design is not a type of energy efficient building even OTTV of the building envelope is $49.79 \mathrm{~W} / \mathrm{m} 2$. Energy consumption of the rooms are in range of $34 \mathrm{kWh} / \mathrm{m} 2 /$ year to $157 \mathrm{kWh} / \mathrm{m} 2 /$ year.
\end{abstract}

Keywords: thermal comfort, energy efficient, tropical humid, students residence

\begin{abstract}
ABSTRAK
Tidak ada informasi bahwa asrama mahasiswa Universitas Sam Ratu Langi didesain hemat energi. Oleh karena itu penting untuk mengevaluasi desain dari sudut pandang konservasi energy yang diasosiasikan dengan pemenuhan kenyamanan dalam ruangan. Melalui penelitian ini, observasi, pengurukan dan penghitungan kenyamanan, ventilasi, panas dan cahaya dilakukan untuk mendapat-kan informasi apabila desain mengikuti standar Indonesia dala hal kenyamanan dan konservasi energy. Kuesioner untuk penghuni dilakukan untuk memperoleh respons pemenuhan terhadap standar kenyamanan. Temperatur udara, kecepatan angin, kelembaban dan cahaya dihitung, secara bersamaan dengan kuesioner mengenai tingkat kenyamanan bagi penguuna. Skala kenyamanan termal di dalam ruangan
\end{abstract}


mengacu pada ISO-7748. Penggunaan alat-alat elektronik seperti computer, kipas angin, TV, dan lain-lain juga dicatat untuk menentukan tingkat konsumsi energy listrik. Hasil secara umum mengindikasikan bahwa terdapat beberapa perbedaan dalam persepsi kenyamanan antara sumber referensi dan responden. Secara umum, desain bukanlah jenis bangunan hemat energy meskipun OTTV dari amplop bangunan adalah 49,79 W/m ${ }^{2}$. Konsumsi energy ruangan rata-rata adalah $34 \mathrm{kWh} /$ m2/tahun sampai $157 \mathrm{kWh} / \mathrm{m} 2 /$ tahun.

Kata kunci: kenyamanan termal, hemat energy, tropis lembab, asrama mahasiswa

\section{INTRODUCTION}

Students Residence of Sam Ratulangi University in Manado are addressed primarily to fulfill the needs of comfortable shelter facilities for students during their study at the University, for both Bachelor and Master's degree program. The building is located in the area of the campus, designed by the Ministry of Housing of the Republic of Indonesia in 2006. The building is expected to meet the standards of comfort and energy conservation, because it is a state-owned buildings used for public purposes (Figure 1 to 3). Currently the building has been occupied by students who need temporary shelter, whether originating from the province of North Sulawesi as well as from other regions (Papua, Gorontalo, Maluku).

Evaluation of energy conservation of the building be conducted through the procedures of research in two parts: energy consumption and indoor comfort with focusing on lighting, heat and ventilation. In principle to achieve comfortable in indoor, the optimal design is required with objective to obtain certain score of comfort and may be justified through the opinion of the occupants. But there is not a statement published that the design of the building is specially designed energy-efficient, and guaranteed its comfort. There are also no reports regarding the calculation of building utility, comfort and energy consumption. Therefore, it is required evaluation of the design through of theoretical approaches and by fact finding through field measurement and information from occupants.

Calculation of illumination and thermal comfort were performed and compared to the results obtained by field measurements. It is hoped that from the results obtained through this evaluation, the building design may be reviewed or improved from the view point of energy conservation.

Residence for students of Sam Ratulangi University is a three-storey building. The land area for this facility is $10,000 \mathrm{~m}^{2}$. The building has a form of type " $\mathrm{H}$ " in plan view, total building floor area of about $3,600 . \mathrm{m}^{2}$ (3 floors for residential and one floor at ground level for public areas and business units). Area of each room (student living space) is $18 \mathrm{~m}^{2}$. 
Roofing material is made of a zinc-alum composite respect to the consideration of lightweight roof structure supporting the resistance to earthquakes. Wall envelope and partition are made of cement brickwork. Height floor to floor is $3.0 \mathrm{~m}$. Floor to ceiling is $2.5 \mathrm{~m}$.

Most of the flats on the second floor at South side have fitted with split AC of $3 / 4 \mathrm{HP}$. Room electrical lighting uses fluorescent lamps (3x12 W with down-light armatures). Figures 1 and 2 show the design and the photographs of the building.

Logically occupancy comfort for the students play an important role to support its core activities of learning. Discomfort in the room could lead to disruption of learning which then result in a decrease in learning achievement. Studies on correlation of temperature and thermal feel have been performed by many authors. Among them is evidenced by the number of field studies or through experimentation in a bioclimatic chamber, as has been done by Berger and Deval (1985), Busch (1992), and De Dear RJ, Leow KG and Ameen A (1991). Field studies by Busch (1992) in Thailand lead to the conclusion that at a temperature of $300 \mathrm{C}$ man can still receive a feeling quite comfortable, although it still needs the help of the breeze. While in cold climates, in general, people feel comfortable at a temperature of about 220C. Lin, TP, et al (2008) also proved the existence of differences in perception between the situation in temperate (Mediterranean) and sub-tropics. According to the SNI 03-6389-2000 (Indonesian Standard, 2000) comfortable air temperature is $(25+1) 0 \mathrm{C}$ and relative humidity is $(60+10) \%$.

Evaluation of temperature and humidity in the rent rooms for student in some houses has been done by 'Harimu' D (2012) in the city of Manado, which lead to the conclusion that the room temperature is comfortable with the Effective Temperature (ET) is 23 to $280 \mathrm{C}$ and only happens on the morning, as resulted of the observation in the period between the hours of 7:00 to 16:00 local time. But the study taken by 'Harimu D is limited only to cases with the existence of sunlight and only on the type of traditional style houses located in a high density area.

With average daily air temperature in Manado that ranges between 22 to $330 \mathrm{C}$, then there is only a short period with a comfortable temperature of about $250 \mathrm{C}$ and usually occurs after midnight until morning. Therefore, if just depend on the natural system, then the period of comfortable time achieved only a few hours. Conversely if we want to get comfortable for longer periods, it is necessary to install the air conditioner (AC). Students certainly need a long spend time for learning in room. Logically, more comfortable the room could function more effective for doing something.

On the other hand, concerning the comfort lighting, it is defined by the building codes that room for learning/reading activity needs support of illumination level of 350 lux, as in accordance with the Indonesia Standard for building energy conservation (SNI 03-6389-2000). But in reality, many of buildings do not follow it because many people are not aware of the comfort standard. But there is conse- 
quence that the addition of illumination means additional power or lamps and resulted in the addition of electrical consumption.

From the study of Suchi Mohanty (2002) concerning lighting in a student library, it is underlined that by increasing the amount of task lighting, these spaces may become more consistent with students' needs.

Some of the paragraphs above show the importance of the study on indoor comfort associated with energy conservation. Moreover we are now in the era of energy efficient and sustainability in all sectors of life in order to save the planet without sacrifice the comfort.

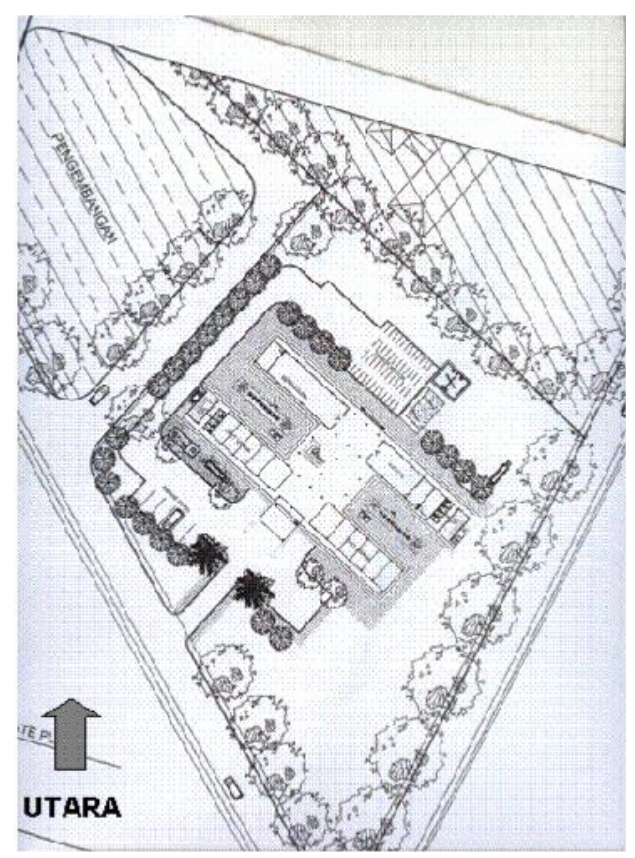

Figure 1. Site Plan
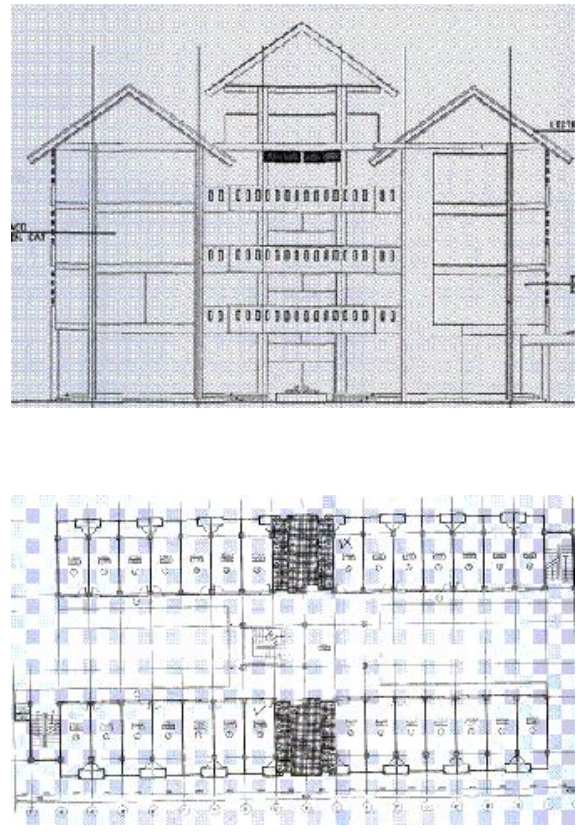

Figure 2. Side Façade and Plan
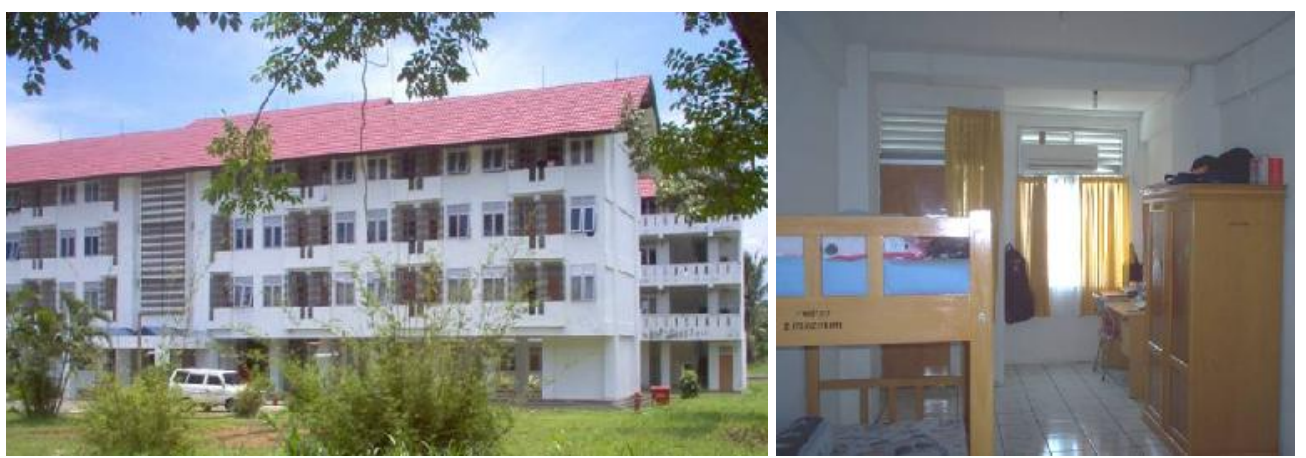

Figure 3. Front Façade and Room Interior 


\section{Research Methods}

In this study, the student residence of Sam Ratulangi University in Manado, have been firstly evaluated from the view point of comfort and conveniences on lighting, ventilation, and thermal. It was then followed by evaluation concerning energy consumption due to the demands of comfort, convenience and health. It was also conducted an evaluation of the electrical energy consumption of electromechanical equipment owned by residents. Indoor climate and lighting measurements were done simultaneously with collecting the responses from questionnaires and technical data collection of the buildings and surrounding areas. The results of measurements, observations and questionnaires, then evaluated and compared with normalizations and national standards or codes of building energy conservation (Figure 4).

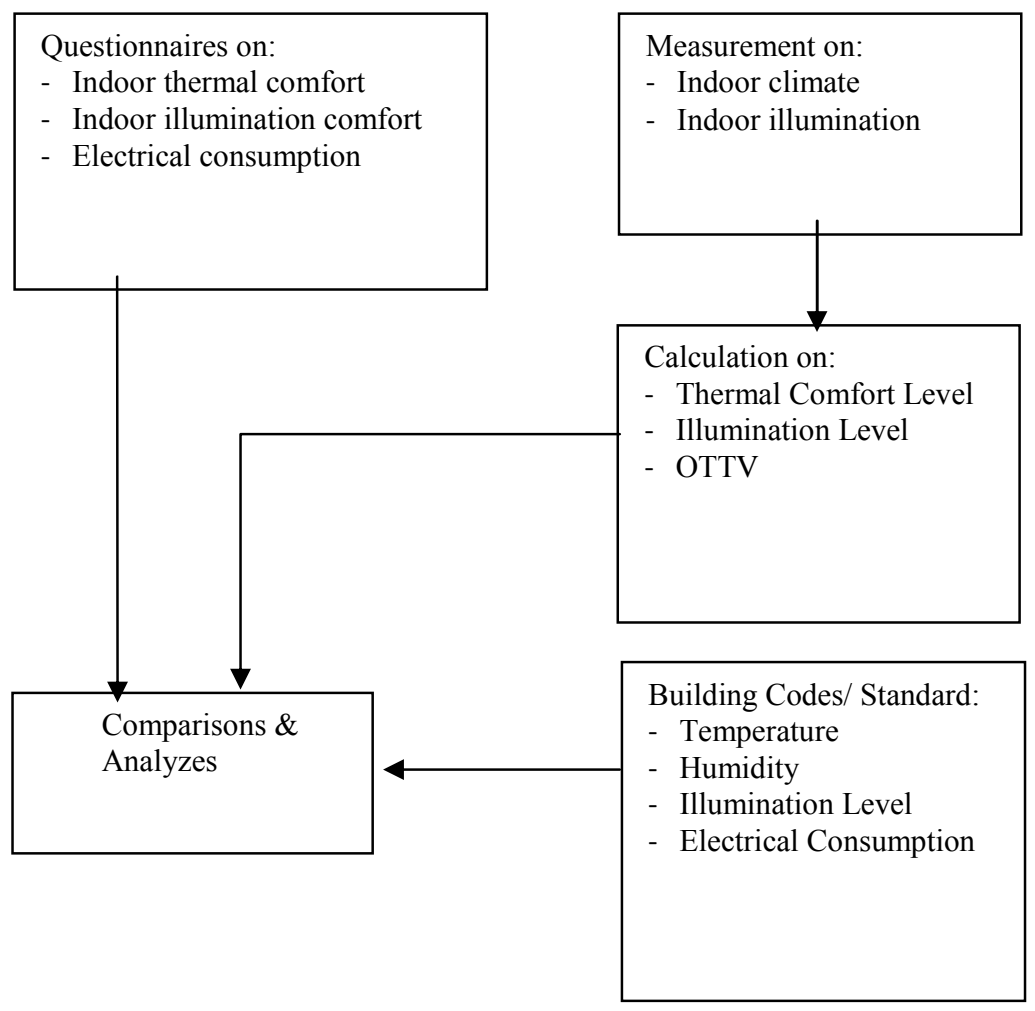

Figure 4. Flowchart of the Method

Measurement and distribution of questionnaires carried out in three rooms on the second floor and on other room on fourth floor. Eight residents participated in filling questionnaires in order to know the response of occupants concerning the adequacy of lighting and thermal comfort level inside the room both during the day and evening. Recording the response on thermal comfort feeling by using a scale or quantification as mentioned in Table 1 and 2, and performed at every two hours for 
one day during the summer and sunny weather, simultaneously with measurements of temperature, humidity and wind speed in rooms.

Table1. Quantification of thermal comfort response

\begin{tabular}{ll}
\hline Thermal Response & Quantification \\
\hline Very Hot/ Very Uncomfortable & +3 \\
Hot/ Uncomfortable & +2 \\
Slightly hot/ Slightly Uncomfortable & +1 \\
Neutral/ Comfortable & 0 \\
Cool & -1 \\
Cold & -2 \\
Very cold & -3 \\
\hline
\end{tabular}

Table 2. Equipments Used for Measurement

\begin{tabular}{ll}
\hline Target of measurement & Equipment used \\
\hline Air temperature & Thermohygrometer \\
Air humidity & Thermohygrometer \\
Air velocity & Hand Anemometer \\
Illumination & Lightmeter \\
\hline
\end{tabular}

In Indonesia, the standard for building energy conservation have been published for the first time in 1993 (published by the Department of Public works) and renewed in 2000 (published by National Standard Bureau) that is SNI 03-6389-2000. The standard determine the quantities for illumination and ventilation requirement based on the function of room. The maximum lighting energy consumption (in units Watt $/ \mathrm{m} 2$ ) of rooms is also determined by the standard. While the effort associated with the efficiency of using air conditioning, also set through the maximum quantity of heat transfer in a term OTTV (Overall Thermal Transmission Value) $=45 \mathrm{~W} / \mathrm{m} 2$ (equation - 1).

$$
O T T V=\alpha\left[U_{W} \times(1-W W R)\right] \times T_{D e q}+(S C \times W W R \times S F)+\left(U_{F} \times W W R\right)
$$

Where $\square=$ absorbtance coefficient of outside wall surface; UW=Thermal transmittance coefficient of the wall system ( $\mathrm{U}$ value); WWR $=$ Window to Wall Ratio; TDEQ= Equivalent difference of temperature between outdoor and indoor ; $\mathrm{SC}=$ Solar Shading Coefficient of the fenestration; $\mathrm{SF}=$ Solar Factor $(\mathrm{W} / \mathrm{m} 2)$.

Solar factor applied in this study determined through estimation using software "Matahari" (Sangkertadi, 2009). Values of solar factor used in this study are that represent of solar radiation on surfaces located in Manado as shown in Table 3. 
Table 3. Solar Factor for Manado

\begin{tabular}{ll}
\hline Position \& Slope of Wall & $\begin{array}{l}\text { Solar Factor } \\
(\mathbf{W} / \mathbf{m} 2)\end{array}$ \\
\hline Vertical North & 157.33 \\
Vertical North-West & 197.98 \\
Vertical West & 224.90 \\
Vertical South-West & 192.71 \\
Vertical South & 150.28 \\
Vertical South-East & 192.90 \\
Vertical East & 224.90 \\
Vertical North-East & 197.79 \\
Horizontal & 459.18 \\
\hline
\end{tabular}

Other equations that used in this study are that to calculate the illumination of artificial lighting which are based on general lighting method as recommended by the Departemen Pekerjaan Umum (1985) (equations 2 and 3).

$$
E=\frac{\Phi_{D} \times U F \times M F}{A}
$$

$$
N=\frac{\Phi_{D}}{\Phi_{L}}
$$

(Where E:Illumination level(lux); UF:Utilization Factor; MF:Maintenance Factor; $\square$ D:lumen received on plane area; $\square \mathrm{L}$ : lumen of the lamp; N: number of lamps)

Calculation method to determine the thermal comfort level refers to the principle of the calculation procedure for the thermal response of the tropical humid climate environment, namely the scale of 'DISC'. Some of DISC equations have been developed by authors such as Berglund \& Cunningham (1986) and Sangkertadi (1994, 1999). In this study, DISC equation by Sangkertadi (1994) was applied, which is a regression equation to define thermal comfort level as functions of two variables: sweat rate and percentage of wet skin. But to determine sweat rate and percentage of wet skin, it has to do at first, calculation of heat transfer between the human and climatic environment surrounding, including the calculation of body metabolism, and heat exchanges through radiative and convective processes. It is underlined, that the DISC model calculation by Sangkertadi (1994) take place the important of air velocity to achieve convective comfort through sweat evaporation.

DISC $=3.9338$ Mcut +0.0158 Ds -0.3348

(Where Mcut: percent of skin wet; Ds: sweat rate in $\mathrm{g} / \mathrm{h}$ ) 
OTTV calculation of the building by using the method as directed in the SNI 036389-2000. The result was then evaluated in order to justify if the building is the type of energy efficient design or not.

Calculation of air changes or ventilation rate in the room was done by using the program 'VENTILA.1.0 (Sangkertadi, 1999), in which the program apply the Bernoulli equation both for multyzone or monozone construction as suggested by the IEA (International Energy Agency) based on the study of Liddament (1996). The result was then evaluated if there is sufficient fresh air change or not in the rooms.

\section{RESULTS AND DISCUSSION}

Discussion on energy savings, the main objectives are focused on efforts to conserve electrical energy or minimizing electricity consumption. Excessive consumption of electrical power is often a consequence of the fulfillment of the demands of convenience that is primed or exceed the standard that are considered normative. Also, still demanded the fulfillment of the adequacy of household goods that also have an impact on energy consumption (Table 4). Limitation the use of energy should ideally not sacrifice comfort and also not hinder the fulfillment of household goods.

Table 4. Electrical Devices Associated with Need of Comfort and Convenience

\section{Parameters of comfort, health and convenience associated with the consequences of energy use}

\begin{tabular}{ll}
\hline Thermal Comfort & Fan, AC \\
Visual Comfort & Lamps \\
Living Convenience : & \\
- Food \& Beverages & Rice cooker, Magic Jar, Coffee Maker, \\
& Electric stove, Refrigerator, etc \\
- Working, Learning & Computer, Printer, additional desk lamps \\
- Cleaning \& Maintenance & Wash machine, iron, water heater, vacuum \\
- Pleasure & cleaner, hair-dryer, etc \\
Adequacy of air change and & Exhaust Fan, AC \\
ventilation &
\end{tabular}

\section{Equipments that require energy}

\author{
Fan, AC
}

Rice cooker, Magic Jar, Coffee Maker, Electric stove, Refrigerator, etc

Computer, Printer, additional desk lamps

TV, Sound system, DVD player

Exhaust Fan, AC

\section{Evaluation of Indoor Temperature and Thermal Comfort}

The results of measurements of air temperature, humidity and air velocity in rooms (both rooms with AC and not) are tabulated in Tables 5 to 9. Observations were conducted during sunny weather, in August 2008. Measurements were performed hourly starting at 08:00 and end at 23:00, with the consideration that, generally in Manado, the climate between the hours of 23:00 to 08:00 is quite comfortable or 
slightly cold, so in those hours, do not require to do more investigation deep. Beside, in those period, in general the students sleep or not in learning activity. In addition, the study by Sangkertadi and Syafriny (2008) resulted that in the period after midnight till morning, in Manado, the indoor climate of housing is quite comfortable. In the period of observation, occupants as respondents, keep doing light activity, such as reading or learning something (assumed approximately $1-1.2 \mathrm{met}$ ), and wore tropical clothing (assuming approximately 0.5 - $0.6 \mathrm{Clo}$ ).

Questionnaires and measurements show that the residents expressed a sense of comfort in an ambient with air temperature of $29^{\circ} \mathrm{C}$, but higher than that point, they stated quite hot. In the room with air temperature of $31.5^{\circ} \mathrm{C}$, they felt a slightly hot, but not too hot. Meanwhile there is one condition when the air temperature was $30^{\circ} \mathrm{C}$ assisted by a momentary breeze of about $0.6 \mathrm{~m} / \mathrm{s}$ has acceptable and felt comfortable according to the respondents. Theoretically, for an individual case, wearing a light tropical clothing, normal body size, and is doing a simple activity, can feel comfortable at a temperature of $29^{\circ} \mathrm{C}$ with a wind speed of about $0.7 \mathrm{~m} / \mathrm{s}$ and relative humidity around $70 \%$ (Figure 5).

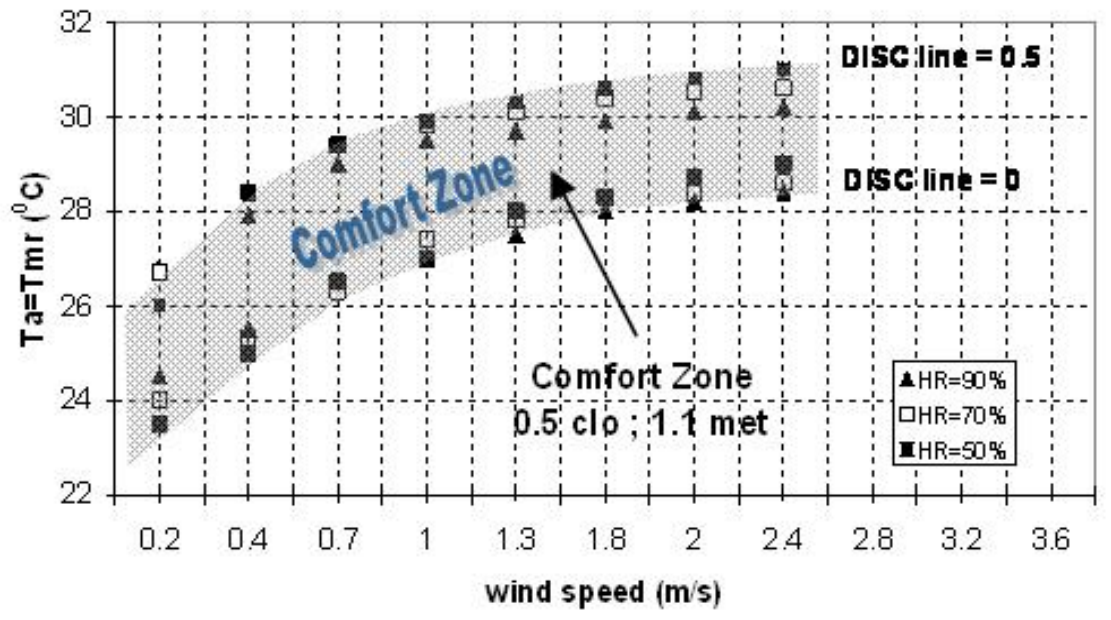

Figure 5. A comfort zone for tropics humid environment Source: Sangkertadi, 1994

The results of the questionnaire were then compared with calculations applying DISC scale, with input data from the measurements. The results show (Tables 8 \& 9) that there is little difference in perception between the calculation and questionnaires. The more important is that there is rather uncomfortable situation both in the rooms (without $\mathrm{AC}$ ) on the second floor and fourth floor. When there such a situation, then there is consequence of spending addition energy for applying fan or even air conditioning.

In rooms installed air conditioning, measurements of air thermal properties were performed at the $\mathrm{AC}$ position, in the center of the room, and at a point farthest from AC. The results show that distribution of air temperature seem quite good in all 
positions, meaning that there is a uniform air circulation in the room, with an average temperature of about $27^{\circ} \mathrm{C}$. There is only $0.8^{\circ} \mathrm{C}$ difference between the lowest and highest temperatures in room. Similarly, the results of air humidity measurement show the same tendency with air temperature. Indoor air speed in the center of room was low (less than $0.02 \mathrm{~m} / \mathrm{s}$ ), and it would not disrupt the activity. In general, the indoor air temperature which is $27.4 \pm 0.4{ }^{\circ} \mathrm{C}$, lead to be concluded that there is no impression of excessive in terms of setting the temperature of air conditioning (Table.7). In humid tropical climates, such as in Indonesia, the temperature is comfortable at about $25{ }^{0} \mathrm{C}$. Indonesia standard SNI 03-6389-2000 recommend a comfortable temperature at $25+1{ }^{0} \mathrm{C}$. Thus, respondents appear to have respect on energy efficiency to achieve comfort.

Table 5. Summary of Indoor Climate Measurement and Thermal Responses in Rooms on Second Floor (without AC)

\begin{tabular}{|c|c|c|c|c|}
\hline Time & $\begin{array}{l}\text { Room Air } \\
\text { Temperatur } \\
\left({ }^{0} \mathrm{C}\right)\end{array}$ & $\begin{array}{l}\text { Relative } \\
\text { humidity } \\
(\%)\end{array}$ & $\begin{array}{l}\text { Air } \\
\text { velocity } \\
(\mathrm{m} / \mathrm{s})\end{array}$ & $\begin{array}{l}\text { Thermal comfort response } \\
\text { (Majority responses from } \\
\text { questionnaires) }\end{array}$ \\
\hline 08.00 & 28.3 & 68.2 & 0.2 & Comfortable \\
\hline 10.00 & 29 & 65.4 & 0.4 & Comfortable \\
\hline 12.00 & 30.3 & 65 & 0.7 & $\begin{array}{l}\text { Slightly hot/Slightly } \\
\text { uncomfortable }\end{array}$ \\
\hline 14.00 & 28.9 & 73.2 & $<0.2$ & $\begin{array}{l}\text { Slightly hot/Slightly } \\
\text { uncomfortable }\end{array}$ \\
\hline 16.00 & 30.5 & 61 & $<0.2$ & $\begin{array}{l}\text { Slightly hot/Slightly } \\
\text { uncomfortable }\end{array}$ \\
\hline 18.00 & 28.7 & 68.9 & $<0.2$ & $\begin{array}{l}\text { Slightly hot/Slightly } \\
\text { uncomfortable }\end{array}$ \\
\hline 20.00 & 30 & 67 & 0.6 & Comfortable \\
\hline 22.00 & 27.4 & 73.5 & $<0.2$ & Comfortable \\
\hline
\end{tabular}

Table 6. Summary of indoor climate measurement and thermal responses in rooms on fourth floor (without AC)

\begin{tabular}{|c|c|c|c|c|}
\hline Time & $\begin{array}{l}\text { Room Air } \\
\text { Temperatu } \\
\text { r }\left({ }^{0} \mathrm{C}\right)\end{array}$ & $\begin{array}{l}\text { Relative } \\
\text { humidit } \\
\text { y }(\%)\end{array}$ & $\begin{array}{l}\text { Air } \\
\text { velocity } \\
(\mathrm{m} / \mathrm{s})\end{array}$ & $\begin{array}{l}\text { Thermal comfort response } \\
\text { (Majority responses from } \\
\text { questionnaires) }\end{array}$ \\
\hline 08.00 & 28.5 & 67.5 & $<0.2$ & Comfortable \\
\hline 10.00 & 29.1 & 64.4 & 0.3 & $\begin{array}{l}\text { Slightly hot/Slightly } \\
\text { uncomfortable }\end{array}$ \\
\hline 12.00 & 31.5 & 63 & 0.2 & $\begin{array}{l}\text { Slightly hot/Slightly } \\
\text { uncomfortable }\end{array}$ \\
\hline 14.00 & 30.8 & 67.5 & $<0.2$ & $\begin{array}{l}\text { Slightly hot/Slightly } \\
\text { uncomfortable }\end{array}$ \\
\hline 16.00 & 29.6 & 65 & $<0.2$ & $\begin{array}{l}\text { Slightly hot/Slightly } \\
\text { uncomfortable }\end{array}$ \\
\hline 18.00 & 28.6 & 70 & $<0.2$ & Comfortable \\
\hline
\end{tabular}




\begin{tabular}{lllll}
\hline 20.00 & 32 & 60 & $<0.2$ & $\begin{array}{l}\text { Slightly hot/Slightly } \\
\text { uncomfortable }\end{array}$ \\
22.00 & 29.2 & 67.7 & $<0.2$ & $\begin{array}{l}\text { Slightly hot/Slightly } \\
\text { uncomfortable }\end{array}$ \\
\hline
\end{tabular}

Table7. Air Temperature and Humidity in a Room Installed AC

\begin{tabular}{lllll}
\hline No & $\begin{array}{l}\text { Object } \\
\text { Measurements }\end{array}$ & $\begin{array}{l}\text { Position-1 } \\
\text { (Near from } \\
\text { AC) }\end{array}$ & $\begin{array}{l}\text { Position-3 } \\
\text { (Center of } \\
\text { room) }\end{array}$ & $\begin{array}{l}\text { Position-1 } \\
\text { (Farthest from } \\
\text { AC })\end{array}$ \\
\hline 1 & Humidity $(\%)$ & 71 & 72.2 & 73.6 \\
2 & Air temperature $\left({ }^{0} \mathrm{C}\right)$ & 27 & 27.4 & 27.8 \\
3 & Wind velocity $(\mathrm{m} / \mathrm{s})$ & 0.4 & $<0.2$ & $<0.2$ \\
\hline
\end{tabular}

Table 8. Thermal Comfort in Rooms on Second Floor (without AC)

\begin{tabular}{|c|c|c|c|c|}
\hline \multirow{3}{*}{ Time } & \multirow{2}{*}{\multicolumn{4}{|c|}{ Indoor Thermal Comfort at second floor }} \\
\hline & & & & \multirow[b]{2}{*}{ Evaluation } \\
\hline & DISC & Feel & By Questionnaire & \\
\hline 08.00 & 0.13 & Comfortable & Comfortable & Natural ventilation \\
\hline 10.00 & 0.13 & Comfortable & Comfortable & Natural ventilation \\
\hline 12.00 & 0.35 & Comfortable & $\begin{array}{l}\text { Slightly hot/Slightly } \\
\text { uncomfortable }\end{array}$ & $\begin{array}{l}\text { May be require } \mathrm{AC} \\
\text { or Fan }\end{array}$ \\
\hline 14.00 & 0.57 & $\begin{array}{l}\text { Slightly } \\
\text { hot/Slightly } \\
\text { uncomfortable }\end{array}$ & $\begin{array}{l}\text { Slightly hot/Slightly } \\
\text { uncomfortable }\end{array}$ & Require AC or Fan \\
\hline 16.00 & 0.86 & $\begin{array}{l}\text { Slightly } \\
\text { hot/Slightly } \\
\text { uncomfortable }\end{array}$ & $\begin{array}{l}\text { Slightly hot/Slightly } \\
\text { uncomfortable }\end{array}$ & Require AC or Fan \\
\hline 18.00 & 0.52 & $\begin{array}{l}\text { Slightly } \\
\text { hot/Slightly } \\
\text { uncomfortable }\end{array}$ & $\begin{array}{l}\text { Slightly hot/Slightly } \\
\text { uncomfortable }\end{array}$ & Require AC or Fan \\
\hline 20.00 & 0.31 & Comfortable & Comfortable & Natural ventilation \\
\hline 22.00 & 0.26 & Comfortable & Comfortable & Natural ventilation \\
\hline
\end{tabular}


Table 9. Thermal Comfort in Rooms on Fourth Floor (without AC)

\begin{tabular}{|c|c|c|c|c|}
\hline \multirow{3}{*}{ Time } & \multirow{2}{*}{\multicolumn{4}{|c|}{$\begin{array}{l}\text { Indoor Thermal Comfort at fourth floor } \\
\text { By Calculation (DISC) }\end{array}$}} \\
\hline & & & & \\
\hline & DISC & Feel & By Questionnaire & Evaluation \\
\hline 08.00 & 0.50 & Comfortable & Comfortable & $\begin{array}{l}\text { Natural } \\
\text { ventilation }\end{array}$ \\
\hline 10.00 & 0.25 & Comfortable & $\begin{array}{l}\text { Slightly hot/Slightly } \\
\text { uncomfortable }\end{array}$ & $\begin{array}{l}\text { Require } \mathrm{AC} \text { or } \\
\text { Fan }\end{array}$ \\
\hline 12.00 & 0.97 & $\begin{array}{l}\text { Slightly hot/Slightly } \\
\text { uncomfortable }\end{array}$ & $\begin{array}{l}\text { Slightly hot/Slightly } \\
\text { uncomfortable }\end{array}$ & $\begin{array}{l}\text { Require } \mathrm{AC} \text { or } \\
\text { Fan }\end{array}$ \\
\hline 14.00 & 1.01 & $\begin{array}{l}\text { Slightly hot/Slightly } \\
\text { uncomfortable }\end{array}$ & $\begin{array}{l}\text { Slightly hot/Slightly } \\
\text { uncomfortable }\end{array}$ & $\begin{array}{l}\text { Require } \mathrm{AC} \text { or } \\
\text { Fan }\end{array}$ \\
\hline 16.00 & 0.73 & $\begin{array}{l}\text { Slightly hot/Slightly } \\
\text { uncomfortable }\end{array}$ & $\begin{array}{l}\text { Slightly hot/Slightly } \\
\text { uncomfortable }\end{array}$ & $\begin{array}{l}\text { Require } \mathrm{AC} \text { or } \\
\text { Fan }\end{array}$ \\
\hline 18.00 & 0.53 & $\begin{array}{l}\text { Slightly hot/Slightly } \\
\text { uncomfortable }\end{array}$ & Comfortable & $\begin{array}{l}\text { Uncertainly } \\
\text { require AC or } \\
\text { Fan }\end{array}$ \\
\hline 20.00 & 1.24 & $\begin{array}{l}\text { Slightly hot/Slightly } \\
\text { uncomfortable }\end{array}$ & $\begin{array}{l}\text { Slightly hot/Slightly } \\
\text { uncomfortable }\end{array}$ & $\begin{array}{l}\text { Require } \mathrm{AC} \text { or } \\
\text { Fan }\end{array}$ \\
\hline 22.00 & 0.65 & $\begin{array}{l}\text { Slightly hot/Slightly } \\
\text { uncomfortable }\end{array}$ & $\begin{array}{l}\text { Slightly hot/Slightly } \\
\text { uncomfortable }\end{array}$ & $\begin{array}{l}\text { Require } \mathrm{AC} \text { or } \\
\text { Fan }\end{array}$ \\
\hline
\end{tabular}

\section{Evaluation of Indoor Lighting and Illumination}

Measurement and questionnaire on illumination level on the position of working plane carried out during the day (in absence of artificial lighting) and in the evening. Either in the evening or during the sunny day (afternoon), all of which are answered by the respondents strongly adequacy of lighting. At night, with illumination level of about 70 lux on the working table, theoretically was not quite comfortable to support learning activities, but most respondents thought it is enough bright. Based on the standards of comfort lighting, for study or work activities that require a precisions, as it usually be done by the students, it takes a level of illumination of about 350 lux. So there is a striking difference between the theory or the standard and the opinion of respondents. With only about 70 lux of illumination, may pose problems concerning the health of the eye and may cause of the problem on the concentration of study/work. Based on the measurement results (Table.10), the situation in the room during the day, practically do not meet the minimum levels of illumination as mentioned in the building code (measuring results are in range of 160 and 230 lux), meaning that during the day still need to increase the level of lighting by using additional lighting from lamps. Based on the illumination measurement it can be said that the design of the natural lighting is declared improper from the view point of energy conservation. 
The results from artificial calculation was also indicate that the level of illumination in room which was 72 lux, is also below of the limit value that is permitted by the building code. Meanwhile, a level of illumination recommended for supporting learning activities is 350 lux. Thus the necessary repairs should be increasing illumination by replacement the lamps which higher flux luminous. Obtained result by calculation using equations 2 and 3, that is required to change the lamps of $4 \times 18 \mathrm{~W}$ CFL (Compact Fluorescent Lamp) so that may reach a level of illumination of 350 lux evenly.

In terms of building energy conservation especially of using electrical lamp, it is limited a maximum lighting power of $15 \mathrm{~W} / \mathrm{m} 2$ according to Indonesia Standard. In this building, recommended to use 4 lamps fluorescent @ 18 watts equal to 73 watts, or $3,6 \mathrm{~W} / \mathrm{m} 2$.

Table 10. Measurement and Response of Lighting Performance

\begin{tabular}{|c|c|c|c|c|}
\hline \multirow{3}{*}{$\begin{array}{l}\text { Room and } \\
\text { Location }\end{array}$} & \multicolumn{4}{|c|}{$\begin{array}{l}\text { Indoor Illumination by measurement (lux) and } \\
\text { response from the respondents }\end{array}$} \\
\hline & \multicolumn{2}{|c|}{ Artificial Lighting } & \multicolumn{2}{|c|}{ Day-lighting } \\
\hline & (lux) & Response & (lux) & Response \\
\hline $\begin{array}{l}\text { Room-1, Second } \\
\text { Floor }\end{array}$ & 76 & Sufficient & 230 & Comfortable \\
\hline $\begin{array}{l}\text { Room-2, Second } \\
\text { Floor }\end{array}$ & 70 & Sufficient & 211 & Comfortable \\
\hline $\begin{array}{l}\text { Room-3 Fourth } \\
\text { Floor }\end{array}$ & 82 & Sufficient & 165 & Comfortable \\
\hline $\begin{array}{l}\text { Room-4 Fourth } \\
\text { Floor }\end{array}$ & 79 & Sufficient & 188 & Comfortable \\
\hline
\end{tabular}

\section{Evaluation of OTTV}

Evaluation of 'OTTV' on the building envelope needs to be done to determine the appropriateness of the design to the national standards for building energy conservation. According to the standard, recommended maximum of 'OTTV' is $45 \mathrm{~W} / \mathrm{m}^{2}$. So the building will be declared as energy efficient building if 'OTTV' is less than 45 $\mathrm{W} / \mathrm{m}^{2}$.

By using equation 1 , it is obtained 'OTTV' $=49.79 \mathrm{~W} / \mathrm{m}^{2}$, which is the value that exceed the maximum recommended $\left(45 \mathrm{~W} / \mathrm{m}^{2}\right)$. Tables 11 to 13 show the summary of data and results of the calculations. The window at a one side of the building which is consisted of clear glass and totally exposed to the sun (Figure.2) may cause the amount of solar radiation that penetrates the glasses and transmit a much of heat quantity into the room. This is the reason of increasingly the value of OTTV. So if the window is protected by a solar shading that may give a shading coefficient maximum 50\%, the value of 'OTTV' may be reduced and lower than $45 \mathrm{~W} / \mathrm{m}^{2}$. With 
'OTTV' greater than $45 \mathrm{~W} / \mathrm{m}^{2}$, then there is a heavy cooling load when operating air conditioning.

Table 11. OTTV calculation for façade North East and South West

\begin{tabular}{llll}
\hline Components \& Coeff. & Unit & $\begin{array}{l}\text { Façade } \\
\text { North East }\end{array}$ & South West \\
\hline Window area & $\mathrm{m}^{2}$ & 53.76 & 53.76 \\
Wall area & $\mathrm{m}^{2}$ & 294 & 294 \\
WWR & & 0.18 & 0.18 \\
Transmission Coeff. of Glass Window & & 0.9 & 0.9 \\
$\mathrm{U}_{\mathrm{w}}$ & $\mathrm{W} / \mathrm{m} \mathrm{K}$ & 2.8 & 2.8 \\
$\mathrm{U}_{\mathrm{f}}$ & $\mathrm{W} / \mathrm{m} \mathrm{K}$ & 5.2 & 5.2 \\
$\mathrm{a}$ & & 0.7 & 0.7 \\
$\mathrm{~T}_{\text {Deq }}$ & ${ }^{\circ} \mathrm{C}$ & 10 & 10 \\
$\Delta \mathrm{T}$ & ${ }^{\circ} \mathrm{C}$ & 5 & 5 \\
$\mathrm{SC}$ & & 0.95 & 0.95 \\
$\mathrm{SF}$ & $\mathrm{W} / \mathrm{m}^{2}$ & 197.79 & 192.71 \\
Calculation for OTTV & & & 0 \\
Conduction through wall & $\mathrm{W} / \mathrm{m}^{2}$ & 16.02 & 16.02 \\
Transmission through window & $\mathrm{W} / \mathrm{m}^{2}$ & 34.36 & 33.48 \\
Conduction through glass window & $\mathrm{W} / \mathrm{m}^{2}$ & 4.75 & 4.75 \\
OTTV partially & $\mathrm{W} / \mathrm{m}^{2}$ & 55.13 & 54.25 \\
\hline
\end{tabular}

Table 12. OTTV calculation for façade South East and North West

\begin{tabular}{llll}
\hline Components \& Coeff. & Unit & $\begin{array}{l}\text { Façade } \\
\text { North East }\end{array}$ & South West \\
\hline Window area & $\mathrm{m}^{2}$ & 0 & 0 \\
Wall area & $\mathrm{m}^{2}$ & 42 & 42 \\
WWR & & 0 & 0 \\
Transmission Coeff. of Glass Window & & 0.9 & 0.9 \\
$\mathrm{U}_{\mathrm{w}}$ & $\mathrm{W} / \mathrm{m} \mathrm{K}$ & 2.8 & 2.8 \\
$\mathrm{U}_{\mathrm{f}}$ & $\mathrm{W} / \mathrm{m} \mathrm{K}$ & 5.2 & 5.2 \\
$\mathrm{a}$ & & 0.7 & 0.7 \\
$\mathrm{~T}_{\text {Deq }}$ & ${ }^{\circ} \mathrm{C}$ & 10 & 10 \\
$\Delta \mathrm{T}$ & ${ }^{\circ} \mathrm{C}$ & 5 & 5 \\
$\mathrm{SC}$ & & 0.95 & 0.95 \\
$\mathrm{SF}$ & $\mathrm{W} / \mathrm{m}^{2}$ & 197.98 & 192.90 \\
Calculation for OTTV & & & 0 \\
Conduction through wall & $\mathrm{W} / \mathrm{m}^{2}$ & 19.6 & 19.6 \\
Transmission through window & $\mathrm{W} / \mathrm{m}^{2}$ & 0 & 0 \\
Conduction through glass window & $\mathrm{W} / \mathrm{m}^{2}$ & 0 & 0 \\
OTTV partially & $\mathrm{W} / \mathrm{m}^{2}$ & 19.6 & 19.6 \\
\hline
\end{tabular}


Table 13. OTTV final

\begin{tabular}{llll}
\hline Facade & $\begin{array}{l}\text { OTTV } \\
\left(\mathbf{W} / \mathbf{m}^{2}\right)\end{array}$ & $\begin{array}{l}\text { Area } \\
\left.\mathbf{( m}^{\mathbf{2}}\right)\end{array}$ & $\begin{array}{l}\mathbf{O T T V} \mathbf{i} \mathbf{x} \\
(\mathbf{W})\end{array}$ \\
\hline North-West & 19.6 & 42 & 823.2 \\
North-East & 55.13 & 294 & 16207.9 \\
South-West & 54.25 & 294 & 15948.5 \\
South-East & 19.6 & 42 & 823.2 \\
Roof & 47.04 & 126 & 5927.0 \\
SUM & & 798 & 39729.9 \\
OTTV-Final & 49.79 & & \\
\hline
\end{tabular}

\section{Evaluation of Electronics Equipment}

Other factors that need to be evaluated related to building energy consumption, is electromechanical equipments to support life requirement of the occupants every day. Table 14 shows the results on the use of equipment that affects the electrical energy of the building. It is found in a one room there is complete electromechanical equipment like as a family in a house. The room is occupied by two students which are economically is above the average of students. Use of equipment such as table lamps, TV, food heater, water dispenser, computer, sometimes until it reaches more than 10 hours daily according to information from the respondent, by reason of the needs of life and convenience. Mindset that should be minimum in electricity consumption, seems have not embedded on the respondents themselves. They think because they pay, then have right to maximize utilization of equipments with the consequences of the increasing consumption on electrical energy. While it is found in another room use only electromechanical equipment for a minimum life requirement, like of most of low-middle class students who rents rooms.

Assumed that in one year the residents stay logically in along 300 days, obtained that figure of energy consumption is vary from 34.2 to $157 \mathrm{kWh} / \mathrm{m} 2 /$ year, or if using students unit is vary from 307.8 to $1413 \mathrm{kWh} /$ student/year. Only one room that consume electricity smaller than $500 \mathrm{kWh} / \mathrm{student} / \mathrm{year}$. To say if this finding is categorized wasteful or energy efficient, it should be compared to other studies. A study for comparison is the study of B Golotti (2009) for case of student housing in Pennsylvania that average electricity consumption of a student is nearly 500 $\mathrm{kWh} /$ student/year. While based on data International Energy Agency (IEA) 2010, electricity consumption in Indonesia reached $591 \mathrm{kWh}$ per capita. From the two comparisons, it is found that the energy consumption of the building in this study considered greater than average, or classified as wasteful electricity. 
Table 14. Distribution of Energy Consumption in Rooms

\begin{tabular}{|c|c|c|c|c|c|c|c|c|c|}
\hline \multirow[t]{2}{*}{ Rooms } & \multirow{2}{*}{$\begin{array}{l}\text { Num } \\
\text { ber } \\
\text { of } \\
\text { Occu } \\
\text { pant }\end{array}$} & \multirow{2}{*}{$\begin{array}{l}\text { Electronic } \\
\text { Equipments }\end{array}$} & \multirow{2}{*}{$\begin{array}{l}\text { Electrical } \\
\text { Power } \\
\text { (watt) }\end{array}$} & \multirow{2}{*}{$\begin{array}{l}\text { Operating } \\
\text { Daily } \\
\text { (hours) }\end{array}$} & \multirow{2}{*}{$\begin{array}{l}\text { Power/ } \\
\text { Room } \\
\text { (watt) }\end{array}$} & \multicolumn{4}{|c|}{ Electricity consumption } \\
\hline & & & & & & $\begin{array}{l}(w h / \\
\text { day })\end{array}$ & $\begin{array}{l}\text { Wh/ } \\
\text { room/ } \\
\text { day }\end{array}$ & $\begin{array}{l}\text { kWh/ } \\
\text { m²/year }^{2}\end{array}$ & $\begin{array}{l}\mathbf{k W h} / \\
\text { student } \\
\text { /year }\end{array}$ \\
\hline \multirow{8}{*}{$\begin{array}{l}\text { Room on } \\
\text { second } \\
\text { floor } \\
\text { (without } \\
\text { AC) }\end{array}$} & \multirow[t]{8}{*}{2} & Ceiling Lamps & $3 \times 12$ & 10 & & 360 & & & \\
\hline & & Iron & 300 & 1.5 & & 450 & & & \\
\hline & & Computer & 400 & 4 & & 1600 & & & \\
\hline & & Fan & 40 & 5 & & 200 & & & \\
\hline & & Sound system & 30 & 2 & 1381 & 60 & 9420 & 157.00 & 1413 \\
\hline & & TV & 75 & 10 & & 750 & & & \\
\hline & & Water dispenser & 150 & 12 & & 1800 & & & \\
\hline & & Food heater & 350 & 12 & & 4200 & & & \\
\hline \multirow{5}{*}{$\begin{array}{l}\text { Room on } \\
\text { fourth } \\
\text { floor } \\
\text { (without } \\
\text { AC) }\end{array}$} & \multirow[t]{5}{*}{2} & Ceiling Lamps & $3 \times 12$ & 12 & & 432 & & & \\
\hline & & Iron & 300 & 1 & & 300 & & & \\
\hline & & Computer & 400 & 3 & 796 & 1200 & 2052 & 34.2 & 307.8 \\
\hline & & Fan & 35 & 2 & & 70 & & & \\
\hline & & Sound system & 25 & 2 & & 50 & & & \\
\hline \multirow{5}{*}{$\begin{array}{l}\text { Room on } \\
\text { second } \\
\text { floor } \\
\text { (with } \\
\text { AC) }\end{array}$} & \multirow[t]{5}{*}{2} & Lamps & $3 \times 12$ & 8 & & 288 & & & \\
\hline & & Iron & 350 & 1 & & 350 & & & \\
\hline & & Computer & 400 & 2 & 1586 & 800 & 8238 & 137.30 & 1235.7 \\
\hline & & Water dispenser & 200 & 10 & & 2000 & & & \\
\hline & & $\mathrm{AC}$ & 600 & 8 & & 4800 & & & \\
\hline \multirow{7}{*}{$\begin{array}{l}\text { Room on } \\
\text { second } \\
\text { floor } \\
\text { (with } \\
\text { AC) }\end{array}$} & \multirow[t]{7}{*}{2} & Ceiling Lamps & $3 \times 12$ & 8 & & 288 & & & \\
\hline & & Iron & 300 & 1 & & 300 & & & \\
\hline & & Computer & 400 & 2 & & 800 & & & \\
\hline & & Water dispenser & 200 & 10 & 1826 & 2000 & 9348 & 155.80 & 1402.2 \\
\hline & & Rice cooker & 250 & 4 & & 1000 & & & \\
\hline & & Desk lamp & 40 & 4 & & 160 & & & \\
\hline & & $\mathrm{AC}$ & 600 & 8 & & 4800 & & & \\
\hline
\end{tabular}

\section{Evaluation of Occupants Density and Ventilation Rate}

Density and ventilation take effect on energy consumption because it is associated with the need for the use of mechanical ventilation (ventilator/fan) to assist fresh air change to meet the health criteria of indoor air. Room with high people densities require adequate ventilation. It is therefore necessary calculations to determine the indoor air change rate associated with human density, as provided in national standards, SNI 03-6572-2001. It is mentioned by the standard, the ventilation openings of not less than $5 \%$ of room floor area that requires ventilation, and its direction is facing: the open area, outdoor terrace, parking lot, or similar. The typical rooms of the building that are without $\mathrm{AC}$ or which depend on natural ventilation system have ventilation openings $0.88 \mathrm{~m}^{2}$. Room floor area is $18 \mathrm{~m}^{2}$, therefore percentage of ventilation openings of the floor area is $4.89 \%$ (still less than 5\%). But when the windows are opened, ventilation openings are larger and may reach optimum $1.52 \mathrm{~m}^{2}$ or $8.44 \%$ of room floor area. From this discussion, it is recommended that the ventilation openings should be more larger in order to reach minimum percentage $5 \%$ of room floor area without open the windows.

Other evaluation concern on the limitation of occupants density in room. Department of Public Works (Departemen Pekerjaan Umum, 2004) has published stan- 
dardization for low cost housing that indicate minimum space for indoor living is 9 $\mathrm{m} 2 /$ person, and may be applied to evaluate the student residence. In fact the rooms of the residence are occupied by maximum 2 persons. Floor area is $18 \mathrm{~m} 2$ so that the density is $9 \mathrm{~m} 2$ /person and match with the standard.

Next analyze is that to evaluate air volume rate of ventilation requirement for occupants. SNI 03-6572-2001 determine ventilation rate for bedroom in a house is $0.3 \mathrm{~m} 3 / \mathrm{min} /$ person. Calculation of ventilation rate were performed in this study using computer program Ventila.1.0 created by Sangkertadi (1998). The program based on ventilation calculation model as recommended by IEA (Liddament, 1996). By applying the assumption that the wind speed in outside is relatively low $(2 \mathrm{~m} / \mathrm{s})$ and wind direction that skew on the openings wall, the ventilation flow rate obtained is $0.21 \mathrm{~m}^{3} / \mathrm{s}$, and the air change rate of $13.9 \mathrm{vol} / \mathrm{h}$. The number is converted into 12.6 $\mathrm{m}^{3} / \mathrm{min}$, which means exceeding the minimum limit of $0.3 \mathrm{~m}^{3} / \mathrm{min} /$ person.

\section{CONCLUSIONS}

This paper describes one manner to evaluate the building performance against the context of building energy conservation, through compliance approach comfort, health and human satisfaction. Increased comfort, quality of health and life satisfaction have an impact on the consequences of an adequate energy supply. As applied to the case of students residence of Sam Ratulangi University in Manado. The parameters evaluated include the energy requirements to meet the thermal comfort and lighting, ventilation, and equipments for residential satisfaction. Analysis is supported by the norms and guidelines of national standards relating to building design, the technical design standards of energy conservation in buildings as well as the thermal comfort standard. The results show that the building does not meet the energy efficient design criteria which were reviewed against the rate of heat transfer through the building envelope into room. Even OTTV reach to $49.49 \mathrm{~W} / \mathrm{m}^{2}$. But energy for lighting system may be lower than maximum limit of the standards. Respondents in general do not have a sense of responsibility on the importance of energy saving measures, such as efforts to minimize power consumption for the electromechanical equipment for satisfying life. Based on these evaluations, it is recommended that the Government needs to review the design of student residence as in this case. The management the residence also need to socialize the importance of electricity saving measures in rooms.

\section{REFERENCES}

Badan Standarisasi Nasional (2000), SNI 03-6389-2000, Standar konservasi energi pada selubung bangunan gedung, Badan Standarisasi Nasional, Indonesia.

Badan Standarisasi Nasional (2001), SNI 03-6572-2001, Tata cara perancangan sistem ventilasi dan pengkondisian udara pada bangunan gedung, Badan Standarisasi Nasional, Indonesia, 2001. 
Departemen Pekerjaan Umum (2004), Pedoman Umum Rumah Sehat, Departemen Pekerjaan Umum, 2004

Departemen Pekerjaan Umum (1985), Standar Penerangan Buatan Dalam Gedung, Departemen Pekerjaan Umum, YLPMB, Bandung.

Berger X., and Deval J. C. (1985), About Thermal Comfort in Humid Tropical Climates. Proceedings of VVS Congres - CLIMA 2000 - Indoor Climate, Copenhagen, 1985.

Berglund L G, Cunningham D. J. (1986), Parameters of Human Discomfort in Warm Environment, ASHRAE Transaction, 92 part 2B,

Busch J. F. (1992), A Tale of two populations : thermal comfort in air conditionned and naturally ventilated offices in Thailand, Energy and Buildings, 1992 (18).

Chow W. K., and Fung W. Y. (1994), Investigation of the subjective response to elevated air velocities: climate chamber experiments in Hongkong, Energy and Buildings, 20, 1994.

Cunningham D. J., Berglund L. G. and Fobelets (1985), A Skin Wettedness Under Clothing and Its Relationship to Thermal Comfort in Men and Women, Proceedings of the Clima 2000 World Congress on Heating, Ventilating and Air-Conditioning, Copenhagen, 25-30 August, 1985.

De Dear R. J., Leow K. G., Ameen A. 1991, Thermal Comfort in the Humid Tropics Part 1: Climate Chamber Experiments on Temperature Preferences in Singapore, ASHRAE Transaction, 97.

Deval, J. C. (1984), Le Confort Thermique en Climat tempere, Revue de Physique Appliquee, 1984 (19).

Gollotti, B. (2009), Energy Use in Penn's Student Housing and Techniques to Achieve Energy Reduction, senior seminar papers, University of Pennsylvania

Harimu Debbie A. J. (2012), Studi Hubungan Antara Perkembangan Ruang dengan Kenyamanan Termal di dalam Rumah Panggung Khas Minahasa, Ringkasan Desertasi, Universitas Hasanuddin, Makassar.

Liddament W. Martin (1996), A Guide to Energy Efficient Ventilation, Air Infiltration and Ventilation Centre (AIVC).

Lin, T.-P., Andrade, H., Hwang, R.-L., Oliveira, S., Matzarakis, A. (2008), The comparison of thermal sensation and acceptable range for outdoor occupants between Mediterranean and subtropical climates. Proceedings 18th International Congress on Biometeorology, September 2008.

Mohanty S. (2002.), Physical Comfort in Library Study Environments: Observations in Three undergraduate Settings. A Master's paper for the M.S. in L.S. degree.

Sangkertadi (1994), Contribution a l'etude du comportement thermoaeraulique des batiments en climat tropical humide, Prise en compte de la ventilation naturelle dans l'evaluation du confort, these doctorat, INSA de Lyon, 1994.

Sangkertadi (1998), Simulasi Kenyamanan Termal Untuk Lingkungan Beriklim Tropis Lembab, Jurnal Dimensi Teknik Arsitektur - Lembaga Penelitian Universitas Kristen Petra, 26 Desember 1998.

Sangkertadi (1999), Memperkenalkan Program Komputer Ventila 1.0 Untuk Simulasi Ventilasi Pada Tipe Bangunan Multizona, The Journal of Research 
and Development - Lembaga Penelitian Universitas Sam Ratulangi - Manado, XXI (20), Juni 1999.

Sangkertadi (2009), Petunjuk Pemakaian Program 'Matahari', Fakultas Teknik Unsrat, Manado.

Sangkertadi, Syafriny R, Tungka A. (2008), Thermal Comfort Comparison of Traditional Architecture and Modern Style Housing in North Sulawesi Indonesia, Proceeding of 9th SENVAR+2nd ISESEE, Selangor, Malaysia, 1-3 December 2008 . 